\title{
Direct and Mediating Effects of Auditor Quality on Auditor Size and Performance
}

\author{
Yu-Shu Cheng ${ }^{1}$, Yahn-Shir Chen ${ }^{2} \&$ Yu-Cheng Chen ${ }^{3}$ \\ ${ }^{1}$ Department of Accounting, Kainan University, Taiwan \\ ${ }^{2}$ Department of Accounting, National Yunlin University of Science and Technology, Taiwan \\ ${ }^{3}$ Department of Finance, National Chung Hsing University, Taiwan \\ Correspondence: Yu-Shu Cheng, Department of Accounting, Kainan University. No.1 Kainan Road, Luzhu \\ Shiang, Taoyuan 33857, Taiwan. Tel: 886-5-341-2500 ext. 7915. E-mail: cyushu@gmail.com
}

Received: July 13, 2013

Accepted: September 2, 2013

Online Published: October 28, 2013

doi:10.5539/ibr.v6n11p134

URL: http://dx.doi.org/10.5539/ibr.v6n11p134

\begin{abstract}
In defining audit quality, DeAngelo (1981) assumes no variation in auditor's technical competency in discovering a breach. Instead, we relax this assumption and utilize principal components analysis technique to extract auditor quality from human capital factors of an audit firm. With the auditor quality, this study examines the association between auditor size and performance. In terms of market segment, audit firms are divided into public company audit market firms (PCAMFs) and non-public company audit market firms (NCAMFs). Based on path analysis, we find that auditor size has direct effect on performance and indirect effect through auditor quality. Auditor quality associates with both auditor size and performance positively. In further, auditor size has more contribution to performance of PCAMFs than that of NCAMFs. Auditor quality of PCAMFs explains more variation of financial performance than do NCAMFs. The results indicate that PCAMFs earn more financial performance through the upgrade of auditor quality.
\end{abstract}

Keywords: path analysis, auditor quality, auditor size, performance, audit firms

\section{Introduction}

After Enron, the U.S. Public Company Accounting Oversight Board (PCAOB) pays much more attention to the oversight of quality control over audit firm. Its regular inspections include evaluation of the quality of audit tasks on a specific engagement and review of auditors' practices, operating policies and auditing procedures related to audit quality. In addition, the PCAOB inspections focus on the assessment of professional competency of auditor, assignment of responsibility, continuing professional education program. These inspections indicate that human resources management is an important determinant of audit quality. Further, the U.K. Financial Reporting Council (FRC) solicited the views of parties interested in the audit process with regard to identifying the relevant drivers of audit quality in November 2006. In the light of recent developments, regulators, academics, and investors are concerned more about the audit quality from the perspective of auditor and the role played by the human recourses in an audit firm.

In the original definition of audit quality, DeAngelo (1981) assumes that the probability of discovering a breach is positive and fixed, implying no variation in auditor's competency (Niemi, 2004). Auditor competency in fact varies over different audit firms. An audit firm with skillful and proficient employees will presumably be able to bring closer concordance of the reported earnings with GAAP and is perceived as a high auditor quality firm (Teoh \& Wong, 1993). Consequently, this study relaxes DeAngelo's constant auditor competency assumption and assesses audit quality in terms of human capital of an audit firm. Watkins et al. (2004) indicate that auditor quality is equal to audit quality with the former an audit-firm specific attribute and the latter an audit-specific attribute. Based on Watkins et al. (2004), we term the audit-firm specific audit quality as auditor quality. Further, we maintain that audit firms with high auditor quality render quality service and are rewarded with superior performance. To examine the association between auditor quality and performance constitutes the first purpose of this study.

Prior studies indicate that larger audit firms have valid reputation for higher quality audits (Simunic \& Stein, 1987; Francis \& Wilson, 1988; Palmorse, 1988; DeFond, 1992) and large audit firms earn more fee premium 
over small ones due to their brand name reputation (Francis, 1984; Gul, 1999; Taylor \& Simon, 1999). Large audit firms own abundant resources, such as human capital and information technology, with which to upgrade service quality. Specifically, large firm hires employees with high educational level and much experience and devotes more resources in professional training to foster high auditor quality. Arguably, auditor size is positively associated with auditor quality. To examine the relation between auditor size and auditor quality constitutes our second purpose.

Traditionally, the association between auditor size and performance is positive due to existence of scale economies (Christenson \& Greene, 1976; Darrough \& Heineke, 1978; Gyimah-Brempong, 1987) or brand name reputation (Francis, 1984; Gul, 1999; Taylor \& Simon, 1999). To retain existing clients and thus to earn economic quasi-rents in the long run, incumbent auditors have economic incentive to compromise with the clients and issue an unqualified audit report. Large audit firms with more clients have more client-specific quasi-rents at stake. They have incentive to resist to the pressure from individual client and thus provide quality audit (DeAngelo, 1981). Specifically, large audit firm owns high auditor quality to deliver quality services and thus rewarded with superior performance. Hence, the relation between auditor size and performance is mediated by auditor quality. Apart from its direct effect, we argue that auditor size affects performance indirectly through auditor quality. To examine the direct and indirect effects of auditor size on performance forms our third purpose.

Empirical data of this study are from 1989 to 2006 Census Report of Audit Firms in Taiwan, published by the Financial Supervisory Commission. Audit firms are divided into public company audit market firms (PCAMFSs) and non-public company audit market firms (NCAMFs) in terms of market segmentation. We utilize principal component analysis technique to extract auditor quality from audit firm's human capital related factors identified in earlier studies. Empirical results, based on path analysis, indicate that auditor size has direct effect on performance and indirect effect through auditor quality. Auditor quality associates with both auditor size and performance positively. Further, auditor size has more contribution to performance of PCAMFs than that of NCAMFs. Auditor quality of PCAMFs explains more variation in performance than does NCAMFs, indicating that the former earn more income through the enhancement of auditor quality.

With the findings and by extending prior researches, this study contributes to the auditing literature. First, previous studies examining the issues of audit quality indirectly estimate audit quality from various indicators of audit clients (Becker et al., 1998; Ghosh \& Moon, 2005). Instead, we are the first to measure auditor quality directly from audit firms with results to fill the gap left by prior studies. Second, we document that use of auditor size to assess auditor quality by earlier studies is warranted. Third, our findings possess managerial implication, in particular, to the practitioners in audit firms providing services to public company. Specifically, upgrade of auditor quality leads to improvement of its performance.

The remainder of this study proceeds as follows. Section 2 presents literature review and hypotheses development. Methodology of this study appears in section 3. Section 4 reports the empirical results. We conclude in section 5 .

\section{Literature Review and Hypotheses Development}

For long, there is no single agreed definition of audit quality that can be used as a standard against which actual performance can be assessed (FRC, 2006). As audit quality is unobservable, after DeAngelo (1981), researchers establish a variety of proxy variables instead.

The definition of audit quality in DeAngel (1981) incorporates two primary dimensions, technical competence of an auditor (discovery of any misstatement) and independence of the auditor (willingness to report client's misstatement once discovered) (Watts \& Zimmerman, 1986; Deis \& Giroux, 1992; Niemi, 2004). The technical competence and independence of the auditor de facto can be referred to as the monitoring strength of an audit (Watkins et al., 2004). Some earlier studies including DeAngelo (1981) focus on auditor independence and assume no variation in auditor competency (Niemi 2004; Goldman \& Barlev, 1974; Nichols \& Price, 1976). As no information about technical competency, Deis and Giroux (1992) noted, its influence on audit quality is difficult to disentangle.

Milgrom and Roberts (1990) indicate that the most important specialized input in partnerships is typically the knowledge and abilities of the workers, that is, their human capital. Audit quality hence can be measured from the attributes of human capital of an audit firm, which is suggested by some prior studies. For example, education of auditors is one of the five areas identified by the AICPA to improve the quality of government audits (Meinhardt et al., 1987). Incorporating the auditors' education to depict auditor's quality, Lee et al. (1999) analytically evaluate the effects of the 150-hour rule on the audit market. Investigating the common attributes of quality audits, Aldhizer et al. (1995) identify two human capital-related attributes which are strongly associated 
with audit quality. This includes the in-charge auditor being a certified public accountant (a symbol of professionalism) and general audit knowledge and experience. FRC (2006) reports two human capital-related key drivers of audit quality, including the skill and personal qualities of partners and staffs, and continuous professional development given to audit personnel. After DeAngelo (1981), numerous studies examine issues related to auditor quality (Feltham et al., 1991; Teoh \& Wong, 1993). To the extent that high-quality auditors assure a greater conformance of the financial report with generally accepted accounting principles (GAAP) and less discretion in management of accruals is permitted (Teoh \& Wong, 1993). Namely, an audit firm with more skillful auditors will presumably be able to bring closer concordance of the reported earnings with GAAP and is perceived as a high auditor quality firm.

In practice, product differentiation and overall cost leadership are two commonly used marketing strategies with which to achieve a sustainable competitive advantage and earn abnormal rate of returns in a hostile environment (Hall, 1980; Porter, 1980). Although various product differentiation alternatives exist, superior quality is the most adopted approach to characterize this strategy (Kiechel, 1981). Differentiation by quality insulates a product from rivalry by lowering customer sensitivity to price and protecting the product from other competitive forces that reduce price-cost margins (Porter, 1980). Moreover, high quality products allow a firm to avoid profit-damaging competition based on price (Gale \& Swire, 1977). That is, higher quality enables the firm to charge premium price and generate superior margins (Porter, 1980; Klein \& Leffler, 1981; Shapiro, 1983). Consistent with the arguments above, previous studies report that product quality is positively associated with financial performance, such as return on investment (Schoeffler et al., 1974; Buzzell, 1978; Craig \& Douglas, 1982; Phillips et al., 1983).

As a professional organization, audit firms render services by auditors. With higher auditor quality, the firms provide quality services to earn more fee premium, which serves either as an incentive to produce quality service continuously or as a return on their investment in reputation. Accordingly, this study expects a direct and positive association between auditor quality and performance and advances the following hypothesis.

H1: Auditor quality has a positive and direct effect on performance of an audit firm.

In theory, scale economies exist for an industry when its constituent firms can reduce their average cost or increase their average revenues by expanding firm size (Christenson \& Greene, 1976; Darrough \& Heineke, 1978; Gyimah-Brempong, 1987). Scale economies prevail in the public accounting industry (Banker et al., 2003) and large audit firms earn more fee premium over small ones due to their brand name reputation (Francis, 1984; Gul, 1999; Taylor \& Simon, 1999). Further, earlier studies report a positive association between performance of audit firm and auditor size, measured either by number of partners (Rescho, 1987), number of full-time employees (Collins-Dodd et al., 2004) or by market share (Chen et al., 2008). Accordingly, this study expects a direct and positive relation between auditor size and performance and hypothesizes:

H2: Auditor size has a positive and direct effect on performance of an audit firm.

DeAngelo (1981) states that start-up and client switching costs enable the incumbent auditors to earn client-specific quasi-rents. They as a result have economic incentive to compromise with client by issuing an unqualified audit report. However, larger auditors with more clients have more client-specific quasi-rents at stake if a lack of independence or a low audit quality becomes known. To avoid loss of other quasi-rents, larger auditors have incentive to resist to the pressure from individual client and thus provide quality audit. Further, as an audit firm grows, it owns abundant resources, such as human capital and information technology, with which to upgrade its auditor quality. In addition, the public accounting profession sets up more requirements on auditors in large audit firm compared to that of in small firm. Take continuing profession education (CPE) as an example, partners in large audit firms providing audit services to public companies are required to take at least 100 CPE hours in every 3-year period in Taiwan and 120 CPE hours in some states of the U.S. (Elder et al., 2008). In contrast, the required CPE hours for partner in small audit firm are half of that in large audit firm. Earlier studies indicate that high level of professional training improves auditor's expertise (Grotelueschen, 1990), associates with efficient auditing practices (Wallace \& Campbell, 1988) and task performance of audit judgment (Bonner \& Pennington, 1991). Further, larger audit firms, such as Big international firms, are perceived as high auditor quality firms (Teoh \& Wong, 1993) and have fewer litigation activities than other firms (Palmrose, 1988). In addition, prior studies report a positive association between auditor size and auditor quality (Krishnan \& Schauer, 2000; Colbert \& Murray, 1998; O’Keefe \& Westort, 1992; Palmrose, 1988). Therefore, this study expects that the larger the auditor size the higher the auditor quality and establishes the following hypothesis.

H3: Auditor size has a direct and positive effect on auditor quality. 
Public companies such as listed and OTC corporations are sizeable and always served by large auditors (Francis et al., 1999; Simunic \& Stein, 1987). Venkataraman et al. (2008) use IPO setting to examine the relation between auditor exposure to legal liability and audit quality and audit fees. Their results suggest that both audit quality and audit fees are higher in a higher-litigation regime. To provide attestation services to public companies in Taiwan, an audit firm is required to have more than two partners and thus its size is relatively larger. Further, the Securities and Exchange Act imposes more civil and criminal liabilities on auditors rendering services to public companies to protect investors. Under a heavier legal liability environment, Taiwanese large audit firms devote more resources in the audit engagement to upgrade service quality and thus are rewarded with higher audit fees. As stated earlier, the association between auditor size and performance is positive. Furthermore, we expect that this relation is mediated by auditor quality. Specifically, large audit firm devotes more resources, such as professional training, to enhance auditor quality. Audit firms with high auditor quality render quality audit services and then bring about more businesses and superior performance. To the best of our knowledge, few studies examine the mediating role of auditor quality in the size-performance relationship. This study sets up the following hypothesis to articulate the above expectation.

H4: Auditor size has a significant indirect effect on performance of an audit firm through auditor quality.

\section{Methodology}

\subsection{Path Analysis}

This study applies path analysis to test our hypotheses. A path coefficient indicates the direct effect of a variable (cause) on another variable (effect). An indirect effect occurs when a variable affects an endogenous variable through its effect on some other variable (referred to as intervening variable) (Agresti \& Finaly, 1997). In other words, for causal effects, there are effects that go directly from one variable to a second variable (direct effect) and effects between two variables that are mediated by one or more intervening variables (indirect effects). Sum of direct and indirect effects is the total effect of one variable on another.

Figure 1 presents the path diagram depicting the relationship among auditor size (SIZE), auditor quality $(A Q)$ and financial performance $(P F)$. Figure 1 posits that SIZE affects $P F$ directly but also indirectly through $A Q$. Macro-economic indicator $(G D P)$, an external environment effect on $P F$, is included as a control variable. Both $S I Z E$ and GDP are exogenous variables while $A Q$ and $P F$ are endogenous variables. The direct causal effects of the exogenous variables (SIZE and $G D P)$ on the endogenous variable ( $A Q$ and $P F)$ are shown with straight arrows. The relationship between SIZE and $P F$ can be decomposed into two parts: direct effect and indirect effect through $A Q$. In addition, the effect of the residual term, $r_{\mathrm{u}}$ and $r_{\mathrm{v}}$, is also included.

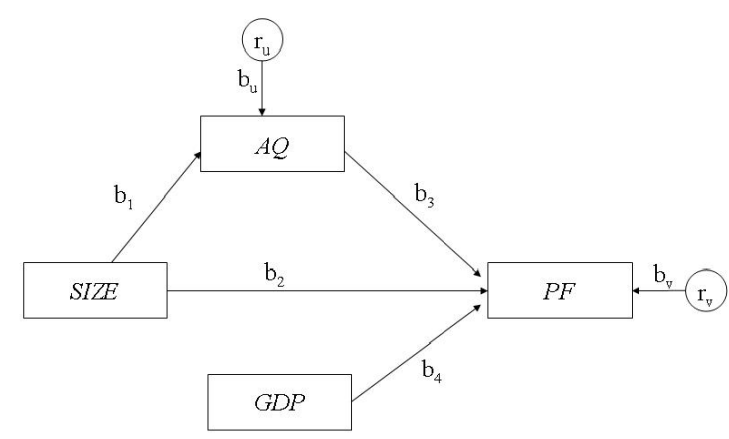

Figure 1. Relation among auditor size, auditor quality and financial performance

These causal relations result in two structural equations as follows:

$$
\begin{gathered}
A Q=b_{1} S I Z E+b_{u} r_{u} \\
P F=b_{2} S I Z E+b_{3} A Q+b_{4} G D P+b_{v} r_{v}
\end{gathered}
$$

where $b_{1}, b_{2}, b_{3}$ and $b_{4}$ are parameter estimates, and $r_{\mathrm{u}}$ and $r_{\mathrm{v}}$ are two residual terms. In examining the $\mathrm{H} 1$, the association between auditor quality and financial performance, we expect a positive $b_{3}$. When testing $\mathrm{H} 2$, the 
direct effect of auditor size on financial performance, this study predicts $b_{2}$ to be positive. We establish $\mathrm{H} 3$ to investigate the relation between auditor size and auditor quality and expect a positive $b_{1}$. As noted earlier, the relationship between SIZE and $P F$ comprises direct effect stated in $\mathrm{H} 2$ and indirect effects depicted in $\mathrm{H} 4$. The indirect effect of auditor size on financial performance through auditor quality is computed by the product of $b_{1}$ and $b_{3}$, which is expected to be positive.

\subsection{Definitions of Variable}

This study defines dependent variable, financial performance $(P F)$, as a natural logarithm of net profit per partner in an audit firm. We take natural $\log$ to normalize its distribution and allow the cross-sectional aggregation of observations. In accounting, net profit is defined as total revenues minus total expenditures. Partners are the owner and residual interest claimant of an audit firm. Their annual income comprises salary and sharing of net profit of the firm. Salary of the partner, weekly or monthly, is a part of total expenditures. According to the Certified Public Accountants Act, net profit of an audit firm should be allocated to the owner annually and cannot be kept as retained earnings. The more the salary of an owner, the less the net profit of the firm. It makes no difference to the partners whether they receive salary or not in terms of their total annual income. In addition, the criteria for salary payments to partners vary across firms. The salary expenses of partners are thus added back to net profit to reduce such an artificial noise. This study thus defines net profit of an audit firm as total revenues minus total expenditures plus the salary paid to the partners.

The first variable of interest in this study is the auditor quality $(A Q)$ extracted by a principal components analysis technique from audit firm's human capital related factors. Meinhardt et al. (1987) summarize an AICPA task force report on the quality of audits of governmental units and indicate that education of auditors is an important area affecting the quality of auditor's work. One of the recommendations made by the task force to the education of auditors is the requirement of auditors to complete relevant continuing professional education programs. Aldhizer et al. (1995) report a 1992 survey findings by the AICPA federal assistance audit quality task force. Some human capital attributes related to auditor are strongly associated with audit quality, including whether an in-charge auditor is a certified public accountant (CPA) (professionalism) and general audit knowledge and experience. In November 2006, the FRC, an independent regulator for corporate reporting and governance in the U.K., issued a provocative discussion paper, Promoting Audit Quality. It identifies the drivers of audit quality in four areas including the skills and personal qualities of audit partners and staff. Specifically, the principal drivers of audit quality in this area include the skill (experience) base of partners and staff, the training given to audit personnel. Adapting Dye's (1993) model, Lee et al. (1999) analytically evaluate the effects of the 150-rule on the audit market and incorporate auditors' education and audit effort as joint inputs of audit quality. Auditors' human capital is one determinant of audit quality and education is a method for auditors to invest and the 150-hour rule is a minimum requirement (Liu, 1997).

Based on the preceding studies, this study extracts auditor quality from four human capital-related factors including educational level of auditors (Lee et al., 1999; Liu, 1997), work experience of auditors (Aldhizer et al., 1995; FRC, 2006), professionalism (Aldhizer et al., 1995), and continuing professional education of auditors (Meinhardt et al., 1987; FRC, 2006). Auditor with bachelor or master degree in accounting had completed at least 150 semester hours of college education to meet the requirement of professional standards (Whittington \& Pany, 2003). Two indicators of educational level of auditors are used to extract auditor quality: number of auditors with bachelor degree (BACHELOR) and number of auditors with master or Ph.D degree (MASTER). Previous studies utilize age of auditor to assess work experience of auditors (Collins-Dodd et al., 2004; Brocheler et al., 2004; Fasci \& Valdez, 1998; Chen et al., 2008). The practitioners argue that auditors older than 35 years old have worked in an audit firm over 10 years and are regarded as a much experienced employee. Three indicators of work experience are included, including number of auditors aged between 35-44 (EXP_35-44), number of auditors aged between 45-54 (EXP_45-54), and number of auditors aged above 55 (EXP_over 55). Passage of the uniform CPA examination together with experience and education requirements, an auditor is awarded with a CPA license and is legible for practicing as an independent auditor. Auditor with a CPA license is equipped with academic and professional expertise and work experience, a symbol of professionalism. This study estimates the professionalism by number of auditors with CPA license (LICENSE). Auditors must meet continuing education requirement to maintain their licenses to practice or as a condition for license renewal (Whittington \& Pany, 2003). Public accounting profession provides continuing professional education to increase the likelihood of appropriate audit quality and to keep auditor stay current on the extensive and ever-changing body of knowledge in accounting, auditing, and taxes (Elder et al., 2008). We define continuing professional education $(C P E)$ as natural logarithm of total training expenses incurred by an audit firm. Another variable of interest in this study is auditor size (SIZE) and is defined as natural logarithm of total 
number of employees of an audit firm. Indicators of educational level of auditors, work experience of auditors, and professionalism are deflated by number of partners to control size of an audit firm. Operational definitions of the variables are summarized as follows.

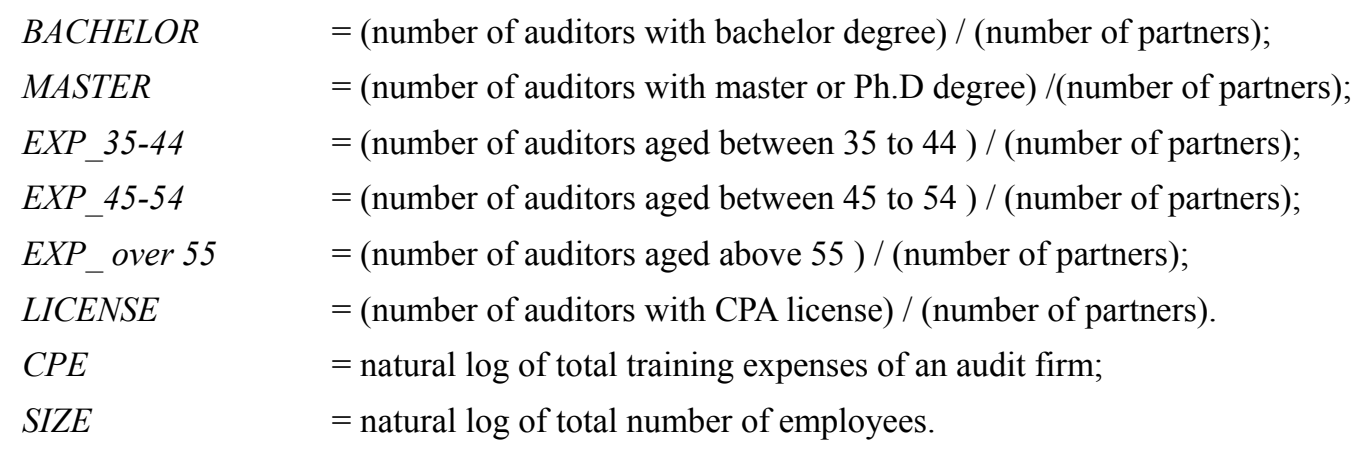

Sample period of this study is 17 years and spans over two centuries. As a professional organization, audit firms are affected by the local economy (Reynolds \& Francis, 2001). A macro-economic indicator, Taiwanese gross domestic product $(G D P)$, is included to control the effects of external environment on operating performance.

\subsection{Data}

Empirical data of this study are obtained from the 1989-2006 Census Report of Audit Firms in Taiwan. Market segmentation to some extent exists in the public accounting profession due to either varied government regulation or size of clients served (Defond et al., 2000; Ghosh \& Lustgarten, 2006). Market segmentation refers to a group of consumers within a broader market who possess a common set of characteristics. Segmentation characteristics include demographic factors, geography, buyer's industry, and size of purchasing firm (Besanko et al., 2000). In terms of market segment, we partition total observations into two categories: public company audit market firms (PCAMFs) and non-public company audit market firms (NCAMFs). During the sample period, we delete firm-year observations (1) newly established in the survey year, (2) with dependent variable having value more than three standard deviations away from its mean, and (3) with no revenue or no expenditure. The final number of firm-year observation is 10,339, including 1,039 PCAMFs and 9,300 NCAMFs.

\section{Empirical Results}

\subsection{Estimation of Auditor Quality}

Table 1 reports the descriptive statistics and correlation matrix of variables used in extracting auditor quality. Panel A lists the results for the total sample while Panels B and C for PCAMFs and NCAMFs, respectively. When Panels $\mathrm{B}$ and $\mathrm{C}$ are compared, mean value of variables in the PCAMFs is higher than that in the NCAMFs except work experience (EXP_35-44, EXP_45-54, and EXP_over55). This indicates that PCAMFs own more auditors with master degree (mean MASTER of the PCAMFs and NCAMFs is 0.3110 and 0.0612 ) and with bachelor degree (mean BACHELOR of the PCAMFs and NCAMFs is 4.8862 and 1.5111). PCAMFs have more auditors with CPA license as compared with NCAMFs (mean number of LICENSE in the PCAMFs is 0.3494 and 0.0649 in the NCAMFs). Also, total training expenses of the PCAMFs are higher than that of NCAMFs (mean $C P E$ for the PCAMFs and NCAMFs is 9.2814 and 5.3539, respectively). In sum, the PCAMFs, on average, have more auditors with higher academic education level and with CPA license. In addition, they devote more resources on the continuing professional education of auditors.

Because more factors determine auditor quality, this study employs a principal components analysis technique to extract it from the previous four human capital-related factors in an audit firm. The eigenvalue-greater-than-one rule suggests that three principal components are obtained and they cumulatively explain about $86 \%$ of total variance. By identifying the attributes of each component, we name the three components as education (including MASTER, BACHELOR and LICENSE), experience (including EXP_35-44, STAF45-54, and EXP_over 55), and training (CPE). As more than one component is extracted, this study applies a linear combination to form a single auditor quality index on basis of the individual component's relative percentage explaining total variance. The linear-combined auditor quality is expressed as follows.

$$
A Q=0.4512 \text { Education }+0.3125 \text { Experience }+0.2363 \text { Training }
$$

\subsection{Descriptive Statistics of Variables Used in Path Model}

Panel A of Table 2 presents the descriptive statistics for variables used in the path model and Panel B displays the testing results of variable differences in mean and median between PCAMFs and NCAMFs. As shown in 
Panel B, SIZE of PCAMFs (mean $=3.9402$, untransformed mean $=119$; median $=3.7377$, untransformed median $=42$ ) is larger than that of NCAMFs (mean $=2.0596$, untransformed mean $=10$; median $=0.1981$, untransformed median $=8)$ significantly $(\mathrm{t}=74.9696 ; \mathrm{z}=47.8490) . A Q$ in PCAMFs (mean $=0.4485$; median $=2.0794)$ is larger than in NCAMFs (mean=-0.0501; median=-0.1513) statistically significantly at the $1 \%$ level $(\mathrm{t}$ $=26.3468 ; \mathrm{z}=22.2634$ ). As the $A Q$ is standardized (mean=0, standard deviation=1), we have negative $A Q$ for the NCAMFs. Further, $P F$ of PCAMFs (mean=14.2290, untransformed mean=1,512,086; median=13.9847, untransformed median=1,184,327) is superior to that of NCAMFs (mean=13.4875, untransformed mean $=720,361$; median $=13.2272$, untransformed median=555,242) significantly $(\mathrm{t}=29.0484 ; \mathrm{z}=23.6323)$. In sum, the PCAMFs tend to be substantially larger in size, higher in auditor quality, and more profitable than NCAMFs.

Table 1. Descriptive statistics and correlation matrix of variables used to extract auditor quality

\begin{tabular}{|c|c|c|c|c|c|c|c|c|c|}
\hline \multicolumn{10}{|c|}{ Panel A: Total sample $(\mathrm{n}=10,339)$} \\
\hline & $\underline{\text { Mean }}$ & $\underline{\text { S.D. }}$ & MASTER & $\underline{B A C H E L O R}$ & EXP $35-44$ & EXP 45-54 & EXP_over 55 & $\underline{L I C E N S E}$ & $\underline{C P E}$ \\
\hline MASTER & 0.0863 & 0.3866 & & $0.1578^{* * *}$ & $0.0839^{* * *}$ & $0.0687^{* * *}$ & $0.0911^{* * *}$ & $0.3931^{* * *}$ & $0.1484^{* * *}$ \\
\hline BACHELOR & 1.8503 & 2.5686 & $0.2595^{* * *}$ & & $0.1546^{* * *}$ & $0.1300^{* * *}$ & $0.0860^{* * *}$ & $0.2797^{* * *}$ & $0.2365^{* * *}$ \\
\hline EXP_35-44 & 0.8078 & 1.2040 & $0.0436^{* * *}$ & $0.1460^{* * *}$ & & $0.1135^{* * *}$ & $0.0617^{* * *}$ & $0.0600^{* * *}$ & -0.0020 \\
\hline$E X P \_45-54$ & 0.2459 & 0.6263 & $0.0190^{*}$ & $0.0335^{* * *}$ & $0.1543^{* * *}$ & & $0.1412^{* * *}$ & $0.0405^{* * *}$ & 0.0093 \\
\hline EXP_over 55 & 0.0573 & 0.2553 & $0.0304^{* * *}$ & 0.0031 & $0.0782^{* * *}$ & $0.1444^{* * *}$ & & $0.0470^{* * *}$ & 0.0083 \\
\hline LICENSE & 0.0935 & 0.4051 & $0.4815^{* * *}$ & $0.3278^{* * *}$ & $0.0469^{* * *}$ & $-0.0191^{*}$ & -0.0016 & & $0.1786^{* * *}$ \\
\hline$C P E$ & 5.7486 & 5.1600 & $0.1389^{* * *}$ & $0.2352^{* * *}$ & $-0.0268^{* * *}$ & $-0.0487^{* * *}$ & $-0.0364^{* * *}$ & $0.1307^{* * *}$ & \\
\hline \multicolumn{10}{|c|}{ Panel B: Public company audit market firms (PCAMF) $(n=1,039)$} \\
\hline MASTER & 0.3110 & 0.8818 & & $0.3694^{* * *}$ & $0.1622^{* * *}$ & $0.1928^{* * *}$ & $0.2037^{* * *}$ & $0.5845^{* * *}$ & $0.3413^{* * *}$ \\
\hline BACHELOR & 4.8862 & 2.2894 & $0.4589^{* * *}$ & & $0.3243^{* * *}$ & $0.2142^{* * *}$ & $0.1556^{* * *}$ & $0.5036^{* * *}$ & $0.4331^{* * *}$ \\
\hline EXP_35-44 & 0.7214 & 1.1274 & $0.0988^{* * *}$ & $0.3448^{* * *}$ & & $0.3135^{* * *}$ & $0.2110^{* * *}$ & $0.1592^{* * *}$ & $0.1378^{* * *}$ \\
\hline$E X P \_45-54$ & 0.0936 & 0.2026 & $0.0628^{* *}$ & $0.0923^{* * *}$ & $0.2031^{* * *}$ & & $0.2336^{* * *}$ & $0.1325^{* * *}$ & $0.1160^{* * *}$ \\
\hline EXP_over55 & 0.0240 & 0.0886 & 0.0399 & 0.0045 & $0.1112^{* * *}$ & $0.1258^{* * *}$ & & $0.1577^{* * *}$ & $0.1322^{* * *}$ \\
\hline LICENSE & 0.3494 & 0.7689 & $0.7943^{* * *}$ & $0.5720^{* * *}$ & $0.1266^{* * *}$ & $0.0518^{* * *}$ & 0.0104 & & $0.3546^{* * *}$ \\
\hline$C P E$ & 9.2814 & 5.0265 & $0.3412^{* * *}$ & $0.3506^{* * *}$ & $0.1149^{* * *}$ & -0.0017 & -0.0916 & $0.3439^{* * *}$ & \\
\hline \multicolumn{10}{|c|}{ Panel C: Nonpublic company audit market firms (NCAMF)(n=9,300) } \\
\hline MASTER & 0.0612 & 0.2704 & & $0.0455^{* * *}$ & $0.0728^{* * *}$ & $0.0350^{* * *}$ & $0.0519^{* * *}$ & $0.2588^{* * *}$ & $0.0501^{* * *}$ \\
\hline BACHELOR & 1.5111 & 2.0337 & 0.0146 & & $0.1473^{* * *}$ & $0.1203^{* * *}$ & $0.0710^{* * *}$ & $0.1547^{* * *}$ & $0.1466^{* * *}$ \\
\hline EXP_35-44 & 0.8174 & 1.2119 & $0.0427^{* * *}$ & $0.1413^{* * *}$ & & $0.0981^{* * *}$ & $0.0467^{* * *}$ & $0.0464^{* * *}$ & $-0.0217^{* *}$ \\
\hline$E X P \_45-54$ & 0.2629 & 0.6547 & $0.0459^{* * *}$ & $0.0815^{* * *}$ & $0.1544^{* * *}$ & & $0.1268^{* * *}$ & 0.0102 & -0.110 \\
\hline EXP_over 55 & 0.0610 & 0.2673 & $0.0542^{* * *}$ & $0.0270^{* * *}$ & $0.0776^{* * *}$ & $0.1416^{* * *}$ & & 0.0040 & $-0.0198^{*}$ \\
\hline LICENSE & 0.0649 & 0.3291 & $0.1863^{* * *}$ & $0.1077^{* * *}$ & $0.0399^{* * *}$ & -0.0067 & 0.0090 & & $0.0600^{* * *}$ \\
\hline$C P E$ & 5.3539 & 5.0230 & $0.0300^{* * *}$ & $0.1262^{* * *}$ & $-0.0362^{* * *}$ & $-0.0328^{* * *}$ & -0.0281 & $0.0260^{* *}$ & \\
\hline
\end{tabular}

Notes: 1. Pearson (Spearman) correlation coefficients are in the lower (upper) triangle.

2. $C P E$ is deflated by consumer price index of the base year, 1989, and expressed in new Taiwan dollars.

3. $\mathrm{n}=$ number of observations. $* * * * *$, and $*$ denote significance at the $1 \%, 5 \%, 10 \%$ level, respectively (two-tailed test)

4. MASTER =(number of auditors with master or Ph.D degree) / (number of partner); BACHELOR =(number of auditors with bachelor degree) / (number of partner); EXP_35-44= (number of auditors aged between 35 to 44 ) / (number of partner); EXP_45-54=(number of auditors aged between 45 to 54 ) / (number of partner); EXP_over55=(number of auditors aged over 55) / (number of partner); LICENSE =(number of auditor with CPA license) $/$ (number of partner), and CPE =natural log of total training expense of an audit firm. 
Table 2. Descriptive statistics of variables used in the path model

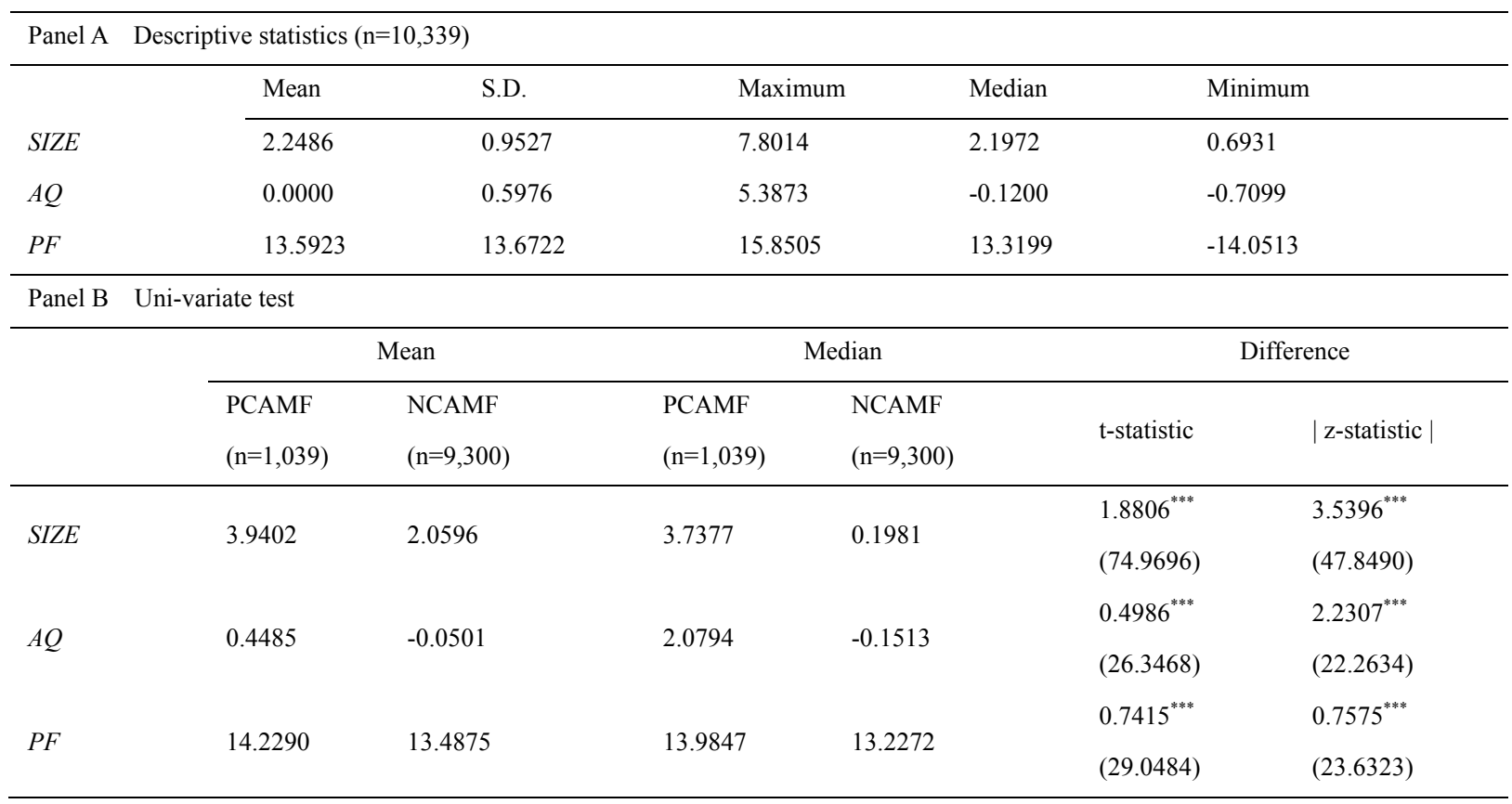

\subsection{Parameter Estimates for Path Model}

Table 3 presents the parameter estimates for equation (1) and (2) in the path model. Panel A lists the results for total sample. As can be seen, SIZE has a positive influence on $A Q$ significantly $\left(b_{I}=0.5140, \mathrm{t}=60.9281\right)$ in equation (1). In equation (2), both SIZE and $A Q$ have a significant effect on $P F\left(\mathrm{~b}_{2}=0.3278, \mathrm{t}=31.4792\right.$ and $\mathrm{b}_{3}=0.1447, \mathrm{t}=13.9168$, respectively). The control variable, $G D P$, is positively related to $P F\left(\mathrm{~b}_{4}=0.0565, \mathrm{t}\right.$ $=6.3305$ ). Parameter estimates for PCAMFs are displayed in Panel B with similar results to that shown in Panel A except the effects of $G D P$ on $P F$. Specifically, SIZE positively affects both $A Q$ and $P F$ significantly, and then $A Q$ positively impacts $P F$ significantly. Panel $\mathrm{C}$ reports the parameter estimates for NCAMFs, which is qualitatively the same as that shown in Panel A for total sample.

As a check on multi-collinearity, the tolerance factor and the variance of inflation factor (VIF) have been applied. The check indicates that all VIFs are less than 4, in econometrics, implying no serious multi-collinearity exists among the independent variables. Next, F statistics, significant at the $1 \%$ level, indicate that equation (1) and (2) are well specified. Further, explanatory power of model (adj. $\mathrm{R}^{2}$ ) for PCAMFs locate between 0.3733 and 0.6783 , higher than that of NCAMFs lying between 0.0649 and 0.1382 .

Additionally, fitness of overall path model to the data $\left(R_{m}^{2}\right)$ can be tested by computing the following generalized squared multiple correlations (Pedhazur, 1982):

$$
R_{m}^{2}=1-\left(1-R_{1}^{2}\right)\left(1-R_{2}^{2}\right) \cdots\left(1-R_{n}^{2}\right)
$$

where $R_{n}^{2}$ denotes the ordinary squared multiple correlation coefficients for the $n$-th regression equation in the model.

For total sample, the adjusted $\mathrm{R}^{2}$ in equation (1) and (2) is 0.2642 and 0.1783 , respectively. Therefore, $R_{m}^{2}$ in the path model can be computed as follows:

$$
R_{\text {total sample }}^{2}=1-(1-0.2642)(1-0.1783)=0.3954
$$

Result above indicates that the overall path model has an obvious improvement of adjusted $\mathrm{R}^{2}$ over their individual regression models, shown in Panel A of Table 3. This implies that the path model fits to the data used by this study. Similarly, $R_{m}^{2}$ of the PCAMFs is $0.7984(=1-(1-0.6783)(1-0.3733))$ and that of NCAMFs is 0.1941 (=1-(1-0.1382)(1-0.0649)), greater than their separate multiple regression models shown in Panels B and $\mathrm{C}$ of Table 3 . Taken the results together, the overall path model has a very well goodness-of-fit. 
Table 3. Standardized parameter estimates of path model

\begin{tabular}{|c|c|c|c|c|c|c|c|}
\hline \multicolumn{8}{|c|}{ Panel A: Total sample $(\mathrm{n}=10,339)$} \\
\hline Cause & Effect & Path & Estimated & & & & \\
\hline variable & variable & coefficient & coefficient & t-statistic & V.I.F. & F-statistic & adj. $R^{2}$ \\
\hline$S I Z E$ & $A Q$ & $b_{1}$ & $0.5140^{* * *}$ & 60.9281 & 1.0000 & $3712.2379^{* * *}$ & 0.2642 \\
\hline SIZE & $P F$ & $b_{2}$ & $0.3278^{* * *}$ & 31.4792 & 1.3644 & & \\
\hline$A Q$ & $P F$ & $b_{3}$ & $0.1447^{* * *}$ & 13.9168 & 1.3608 & $748.7467^{* * *}$ & 0.1783 \\
\hline$G D P$ & $P F$ & $b_{4}$ & $0.0565^{* * *}$ & 6.3305 & 1.0039 & & \\
\hline \multicolumn{8}{|c|}{ Panel B: Public company audit market firms ( PCAMF) $(n=1,039)$} \\
\hline Cause & Effect & Path & Estimated & & & & \\
\hline variable & variable & coefficient & coefficient & t-statistic & V.I.F. & F-statistic & adj. $R^{2}$ \\
\hline$S I Z E$ & $A Q$ & $b_{1}$ & $0.8236^{* * *}$ & 46.7642 & 1.0000 & $2186.8859^{* * *}$ & 0.6783 \\
\hline$S I Z E$ & $P F$ & $b_{2}$ & $0.3473^{* * *}$ & 7.9977 & 3.3123 & & \\
\hline$A Q$ & $P F$ & $b_{3}$ & $0.2938^{* * *}$ & 6.7686 & 3.1202 & $207.1321^{* * *}$ & 0.3733 \\
\hline$G D P$ & $P F$ & $b_{4}$ & -0.0261 & -1.0602 & 1.0048 & & \\
\hline \multicolumn{8}{|c|}{ Panel C: Nonpublic company audit market firms $(\mathrm{NCAMF})(\mathrm{n}=9,300)$} \\
\hline Cause & Effect & Path & Estimated & & & & \\
\hline variable & variable & coefficient & coefficient & $\mathrm{t}$-statistic & V.I.F. & F-statistic & adj. $R^{2}$ \\
\hline SIZE & $A Q$ & $b_{1}$ & $0.3719^{* * *}$ & 38.6287 & 1.0000 & $1492.1803^{* * *}$ & 0.1382 \\
\hline$S I Z E$ & $P F$ & $b_{2}$ & $0.2000^{* * *}$ & 18.4748 & 1.1659 & & \\
\hline$A Q$ & $P F$ & $b_{3}$ & $0.0890^{* * *}$ & 8.2353 & 1.1623 & $215.9629^{* * *}$ & 0.0649 \\
\hline$G D P$ & $P F$ & $b_{4}$ & $0.0740^{* * *}$ & 7.3656 & 1.0049 & & \\
\hline
\end{tabular}

Table 4. Estimates of direct, indirect and total effects of path model

\begin{tabular}{|c|c|c|c|c|c|c|c|c|}
\hline \multicolumn{9}{|c|}{ Panel A: Total sample $(n=10,339)$} \\
\hline \multicolumn{3}{|c|}{ Path ( from $\rightarrow$ to) } & \multicolumn{2}{|c|}{ direct effects (t-statistic) } & \multicolumn{2}{|c|}{ indirect effects(t-statistic) } & \multicolumn{2}{|c|}{ total effects(t-statistic) } \\
\hline$S I Z E$ & $\rightarrow$ & $A Q$ & $0.5140^{* * *}$ & $(60.9281)$ & & & $0.5140^{* * *}$ & $(60.9281)$ \\
\hline$S I Z E$ & $\rightarrow$ & $P F$ & $0.3278^{* * *}$ & $(31.4792)$ & $0.0744^{* * *}$ & $(13.5834)$ & $0.4022^{* * *}$ & (44.6419) \\
\hline$A Q$ & $\rightarrow$ & $P F$ & $0.1447^{* * *}$ & (13.9168) & & & $0.1447^{* * *}$ & (13.9168) \\
\hline$G D P$ & $\rightarrow$ & $P F$ & $0.0565^{* * *}$ & $(6.3305)$ & & & $0.0565^{* * *}$ & $(6.3305)$ \\
\hline \multicolumn{9}{|c|}{ Panel B: Public company audit market firms (PCAMF) $(n=1,039)$} \\
\hline \multicolumn{3}{|c|}{ Path $($ from $\rightarrow$ to $)$} & \multicolumn{2}{|c|}{ direct effects (t-statistic) } & \multicolumn{2}{|c|}{ indirect effects(t-statistic) } & \multicolumn{2}{|c|}{ total effects(t-statistic) } \\
\hline$S I Z E$ & $\rightarrow$ & $A Q$ & $0.8236^{* * *}$ & $(46.7642)$ & & & $0.8236^{* * *}$ & $(46.7642)$ \\
\hline$S I Z E$ & $\rightarrow$ & $P F$ & $0.3473^{* * *}$ & $(7.9977)$ & $0.2420^{* * *}$ & $(6.7142)$ & $0.5893^{* * *}$ & $(23.4667)$ \\
\hline$A Q$ & $\rightarrow$ & $P F$ & $0.2938^{* * *}$ & $(6.7686)$ & & & $0.2938^{* * *}$ & $(6.7686)$ \\
\hline$G D P$ & $\rightarrow$ & $P F$ & -0.0261 & $(-1.0602)$ & & & -0.0261 & $(-1.0602)$ \\
\hline \multicolumn{9}{|c|}{ Panel C: Nonpublic company audit market firms (NCAMF) $(n=9,300)$} \\
\hline \multicolumn{3}{|c|}{ Path $($ from $\rightarrow$ to $)$} & \multicolumn{2}{|c|}{ direct effects (t-statistic) } & \multicolumn{2}{|c|}{ indirect effects(t-statistic) } & \multicolumn{2}{|c|}{ total effects(t-statistic) } \\
\hline$S I Z E$ & $\rightarrow$ & $A Q$ & $0.3719^{* * *}$ & $(38.6287)$ & & & $0.3719^{* * *}$ & $(38.6287)$ \\
\hline$S I Z E$ & $\rightarrow$ & $P F$ & $0.2000^{* * *}$ & (18.4748) & $0.0331^{* * *}$ & $(8.0574)$ & $0.2331^{* * *}$ & $(23.1318)$ \\
\hline$A Q$ & $\rightarrow$ & $P F$ & $0.0890^{* * *}$ & $(8.2353)$ & & & $0.0890^{* * *}$ & $(8.2353)$ \\
\hline$G D P$ & $\rightarrow$ & $P F$ & $0.0740^{* * *}$ & $(7.3656)$ & & & $0.0740^{* * *}$ & $(7.3656)$ \\
\hline
\end{tabular}




\subsection{Estimates of Direct, Indirect and Total Effects of Path Model}

Table 4 reports the estimates of the standardized direct, indirect, and total effects in the path model. As shown in Panel A for total sample firms, SIZE has a direct effect on auditor quality $(A Q)$ significantly $\left(\mathrm{b}_{1}=0.5140\right.$, $\mathrm{t}=60.9281$ ), which supports the H1. Additionally, both $S I Z E$ and $A Q$ are directly and positively associated with $P F\left(\mathrm{~b}_{2}=0.3278, \mathrm{t}=31.4792\right.$ and $\left.\mathrm{b}_{3}=0.1447, \mathrm{t}=13.9168\right)$, which lends a support to the $\mathrm{H} 2$ and $\mathrm{H} 3$. As regards the indirect effect, the relationship between SIZE and $P F$ is being mediated significantly by the $A Q$ and the estimate of indirect effect is $0.0744(\mathrm{t}=13.5834)$. This indicates that auditor size has an indirect effect on financial performance through the upgrade of auditor quality and thus the $\mathrm{H} 4$ receives support.

This indirect effect estimate (0.0744) is calculated as product of the following two effects: the effect of SIZE on $A Q$ (0.5140) and the effect of $A Q$ on $P F(0.1447)$. Therefore, the total effect of SIZE on $P F(0.4022)$ is the sum of direct effect (0.3278) from SIZE to $P F$ and indirect effect (0.0744) from SIZE through $A Q$ to $P F$. That is, each 1 standard unit increase in SIZE increases/improves 0.4022 standard units of $P F$. Further, the direct effect of auditor size explains $81.50 \%(0.3278 / 0.4022)$ of the total variation in financial performance and the indirect effect of auditor quality explain $18.50 \%(0.0744 / 0.4022)$ only. This means that, ceteris paribus, of the one million dollars of financial performance, auditor size creates about $\$ 815,000$ over the $\$ 185,000$ created by auditor quality. In addition, the effect of $G D P$ on $P F$ is positive significantly ( $\mathrm{t}=6.3305$ ).

Panel B of Table 4 displays the results for PCAMFs. As shown, SIZE has a direct effect on $A Q$ significantly $\left(\mathrm{b}_{1}=0.8236, \mathrm{t}=46.7642\right)$, which supports the H1. Further, both $S I Z E$ and $A Q$ are directly and positively related to $P F\left(\mathrm{~b}_{2}=0.3473, \mathrm{t}=7.9977\right.$, and $\mathrm{b}_{3}=0.2938, \mathrm{t}=6.7686$, respectively). This lends a support to the $\mathrm{H} 2$ and $\mathrm{H} 3$. Next, the relationship between SIZE and $P F$ is being mediated significantly by the $A Q$ and the estimate of indirect effect is $0.2420\left(=0.8236^{*} 0.2938\right)(\mathrm{t}=6.7142)$. This indicates that auditor size has an indirect effect on financial performance through auditor quality. Therefore, the H4 is supported. Total effect of SIZE on $P F(0.5893)$ is the sum of direct effect of SIZE on $P F(0.3473)$ and indirect effect of SIZE on $P F$ through $A Q(0.2420)$. The 0.5893 total effect denotes that each 1 standard unit increase in auditor size increases (i.e. improves) 0.5893 standard units of financial performance. Also, it indicates that nearly $58.93 \%(0.3473 / 0.5893)$ of the total variation in financial performance of PCAMF can be accounted for by the direct effect of auditor size and about $41.07 \%$ $(0.2420 / 0.5893)$ by the indirect effect of auditor quality. In addition, the effect of GDP on $P F$ is negative but insignificant.

Estimates of direct, indirect, and total effects for the NCAMFs are listed in Panel C of Table 4. As can be seen, SIZE has a direct effect on $A Q$ significantly $\left(\mathrm{b}_{1}=0.3719, \mathrm{t}=38.6287\right)$. This lends a support to the H1. Both SIZE and $A Q$ are directly and positively related to $P F\left(\mathrm{~b}_{2}=0.2000, \mathrm{t}=18.4748\right.$ and $\mathrm{b}_{3}=0.0890, \mathrm{t}=8.2353$, respectively). Hence, both $\mathrm{H} 2$ and $\mathrm{H} 3$ receive support. Next, the relationship between SIZE and $P F$ is being mediated significantly by the $A Q$ and the estimate of indirect effect is $0.0331(0.3719 * 0.0890)(\mathrm{t}=8.0574)$. This indicates that auditor size has an indirect effect on financial performance through auditor quality and thus supports the H4. The total effect of SIZE on $P F, 0.2331$, denotes that each 1 standard unit increase in auditor size increases/improves 0.2331 standard units of financial performance. The total effect of 0.2331 consists of direct effect of 0.2000 and indirect effect of 0.0331 . Around $85.80 \%(0.2000 / 0.2331)$ of the total variation can be accounted for by the direct effect of auditor size, and about $14.20 \%(0.0331 / 0.2331)$ of the total variation by the indirect effect of auditor quality. Moreover, the direct effect of SIZE on $P F(0.2000)$ is greater than the direct effect of $A Q$ on $P F(0.0890)$. This result shows that auditor size plays a more important role in creating performance than auditor quality. Therefore, auditor size dominates performance creation in the NCAMFs. Like the result for total sample, the effect of GDP on $P F$ is positive significantly $(\mathrm{t}=7.3656)$.

In short, our empirical results provide evidence to support the H1, H2, H3 and $\mathrm{H} 4$ for the total sample, PCAMFs and NCAMFs.

\subsection{Additional Analysis}

To ensure confidentiality of business transactions of audit firm, the Census Report provides no specific information on individual audit firm. Thus, samples used in this study are pooled data, in which both cross-sectional and time series data are combined. In econometrics, pooled data allow researchers to exploit the entire available samples and hence are used by more and more studies. As the results from pooled data reflect a mean effect of independent variables during the sampling period, in consequence, statistics obtained from pooled data are more accurate (Geletkanycz \& Hambrick, 1997). However, pooled data are likely to violate the assumption of independent observations under the ordinary least square method. Error terms are likely to be serially correlated or possess cross-sectional dependence. The significance level of coefficients tends to be overstated. To overcome the conflicting situations, this study conducts an annual analysis of path model and 
utilizes the statistics suggested to compare the coefficients between pooled regression results and yearly results. For the total sample, empirical results (not reported here) are the same as those reported earlier in 15 of the 17 years. For PCAMFs, we have the same findings (not reported here) as those reported earlier in 14 of the 17 years. In contrast, we have the same findings (not reported here) as those reported earlier in 12 of the 17 years for the NCAMFs. Based on the annual analysis, we argue that the empirical results reported previously are robust for the total sample, PCAMFs, and NCAMFs.

\section{Conclusions and Discussions}

\subsection{Discussion of Findings}

This study relaxes constant auditor competency assumption in the definition of audit quality by DeAngelo (1981). We extract auditor quality from the human capital related factors of an audit firm. Empirical results indicate that auditor size has direct effect on performance and indirect effect through auditor quality. Auditor quality associates with both auditor size and performance positively.

The finding of positive association between auditor quality and auditor size, displayed in Tables 3 and 4, justifies the use of size to surrogate audit quality by earlier studies (Simunic \& Stein, 1987; Francis \& Wilson, 1988; Palmorse, 1988; DeFond, 1992; Teoh \& Wong, 1993). In this study, PCAMFs are defined as audit firms providing services to public company. As noted in the Table 2, auditor size of PCAMFs is larger than NCAMFs, consistent with evidence identified by Simunic and Stein (1987) and Francis et al. (1999).

The findings are qualitatively the same for either total sample firms, PCAMFs or NCAMFs. However, differences in degree of effect exist between PCAMFs and NCAMFs. To protect investors, Taiwanese Securities and Exchange Act imposes more civil and criminal liabilities on PCAMFs. In addition, public companies such as listed and OTC corporations are sizeable and always served by large auditors. PCAMFs render attestation services for their IPO, seasoned equity offering, and bank loan. Bankers, potential investors and the public community use the auditor's report for their decision-making. Recently, Taiwan passes the Securities Investor and Futures Trader Protection Act and establishes the Securities Investors and Future Trader Protection Center. The center on behalf of the investors engages in class action against auditors issuing inaccurate audit report. In consequence, more and more auditors are sued and they settle the litigation by paying the investors much money. PCAMFs operate in a relatively higher legal liability and litigation risk regime. To retain clients and competes for new customers, PCAMFs advance auditor quality to provide quality services and in turn are rewarded with superior performance. Table 2 reports that PCAMFs have higher auditor quality and performance than NCAMFs. As larger auditors have valid reputation for higher quality audits, they earn more fee premium over small ones due to brand name reputation. Hence, the above result coincides with prior studies (Francis, 1984; Gul, 1999; Taylor \& Simon, 1999) and in particular with Venkataraman et al. (2008) stating that both audit quality and audit fees are higher in a higher-litigation regime.

For PCAMFs, the total effect of auditor quality on performance is 0.2938 , which is higher than the 0.0890 in the NCAMFs. Auditor size of PCAMFs directly accounts for $58.93 \%$ variation in performance and $41.07 \%$ is explained by its indirect effect through auditor quality. In contrast, $85.80 \%$ variation in performance of NCAMFs is directly accounted for by auditor size and the indirect effect of auditor size through auditor quality explains $14.20 \%$ only. Further, one standard unit increase in auditor size of PCAMFs improves 0.5893 standard unit of performance. In NCAMFs, one standard unit increase in auditor size improves 0.2331 standard unit of performance.

The above results demonstrate that auditor quality of PCAMFs contributes more to the creation of performance compared to that of NCAMFs. Further, PCAMFs have higher degree of effect of auditor size on performance through auditor quality than do NCAMFs. Namely, PCAMFs produce superior performance through the upgrade of auditor quality directly and indirectly. We define auditor quality from the perspective of human capital in an audit firm. By definition, our earlier results imply that PCAMFs employ auditors with higher level of education and higher level of experience to render quality services and thus are rewarded with higher net profit per partner. In contrast, NCAMFs primarily offer services to small and medium- sized enterprises. Most of the services are rendered to meet the tax-law or regulatory requirement and in essence are routine jobs. Such services have homogeneous quality and hence needs similar auditor quality. Consequently, the auditor quality of NCAMFs contributes less to the creation of performance and has lower degree of effect of auditor size on performance through auditor quality compared to the PCAMFs.

\subsection{Conclusion and Implication}

The primary objective of this study is to examine the following research question: whether auditor size has a 
direct effect or indirect effect through auditor quality on firm's performance; whether the extent of association varies between PCAMF and NCAMF. To estimate the indirect effect of auditor quality, a path model is built to identify the indirect links between auditor size and firm's performance mediated by auditor quality.

The empirical results presented in the preceding sections show that auditor size affects firms' performance both directly and indirectly through auditor quality. Of the two effects, both of them play a more important role in creating superior performance. Further, the evidence shows auditor size is positively related to auditor quality and the marginal contribution of auditor size on auditor quality for PCAMF is higher than NCAMF. From the interiors data of public accounting firm, these findings support auditor size is a suitable proxy for auditor quality and demonstrate DeAngelo's (1981) inference: the larger the auditor size, the higher the quality of the auditor. Finally, this study also finds the macro-economic indicator in the NCAMF has a greater influence than the PCAMF in explaining firm's performance, indicating the performance for the NCAMF is easily affected by the macro-economic indicator compared to the PCAMF.

This study contributes to the literature on auditor quality in a number of ways. First, to our knowledge, much less attention has been devoted to the interrelationship among auditor size, auditor quality and firm's performance. This study's major goal was to bridge this gap by presenting and empirically testing a conceptual model that ties up all of those relationships. Second, it has been proposed auditor size is associated with firm's performance. Our research findings provide stronger evidence to support this proposition from the interiors data of public accounting firm. Our findings suggest auditor size alone does not ensure superior performance. This fact does not imply the enlargement of auditor size is not an important factor in creating firm's performance. Rather, it suggests this factor alone is not sufficient to guarantee firm's performance. Only higher quality auditing and auditor size together can create a sufficient condition for superior performance. Third, from a management perspective, the increase and enrichment of the pool of human capital in the audit firm can improve auditor quality. An accounting firm can enhance auditor quality and avoid audit failure by hiring well-educated personnel, providing them with well-planed continuing professional development, encouraging them to acquire professional certificates, and maintaining them within the work environment so that the "best people stay in the profession." In conclusion, to ensure its viability and flexibility and its ability to meet the needs of investors, the audit firm needs to continue to attract, develop, educate and train auditors at all levels that are prepared to perform high quality audits in this dynamic environment. This will lead higher performance improvement. Finally, it should be noted top management should devote considerable efforts to improve their firm's human capital of auditors, in turn, leading to higher auditor quality and thus creating superior performance.

\section{References}

Agresti, A., \& Finlay, B. (1997). Statistical methods for the social sciences. New Jersey: Prentice Hall.

Aldhizer, G. R., Miller, J. R., \& Moraglio, J. E. (1995). Common attributes of quality audits. Journal of Accountancy, 179, 61-68.

Banker, R. D., Chang, H., \& Cunningham, R. (2003). The public accounting industry production function. Journal of Accounting and Economics, 35, 255-281. http://dx.doi.org/10.1016/S0165-4101(03)00021-1

Becker, C. L., DeFond, M. L., Jiambalvo, J., \& Subramanyam, K. R. (1998). The effect of audit quality on earnings management. Contemporary Accounting Research, 15, 1-24. http://dx.doi.org/10.1111/j.1911-3846.1998.tb00547.x

Besanko, D., Danove, D., \& Shanley, M. (2000). Economics of strategy. New York, NY: John Wiley.

Bonner, S. E., \& Pennington, N. (1991). Cognitive processes and knowledge as determinants of auditor expertise. Journal of Accounting Literature, 10, 1-50.

Buzzell, R. D. (1978). Product quality, Strategic. Massachusetts: Planning Institute.

Chen, Y. S., Chang, B. G., \& Lee, C. C. (2008). The association between continuing professional education and financial performance of public accounting firms. The International Journal of Human Resources Management, 19, 1720-1737. http://dx.doi.org/10.1080/09585190802295363

Christensen, L. R., \& Greene, W. H. (1976). Economies of scale in U.S. electric power generation. Journal of Political Economy, 84, 655-676. http://dx.doi.org/10.1086/260470

Colbert, G., \& Murray, D. (1998). The association between auditor quality and auditor size: An analysis of small CPA firms. Journal of Accounting, Auditing and Finance, 13, 135-150.

Collins, D., Gordon, C. I., \& Smart, C. (2004). Further evidence on the role of gender in financial performance. Journal of Small Business Management, 42, 395-417. http://dx.doi.org/10.1111/j.1540-627X.2004.00119.x 
Craig, S. S., \& Douglas, S. P. (1982). Strategic factors associated with market and financial performance. Quarterly Review of Economics and Business, 22, 101-112.

Darrough, M., \& Heineke, J. (1978). The multiproduct production cost function: The case of law enforcement agencies. Amsterdam: North-Holland.

DeAngelo, L. E. (1981). Auditor size and audit quality. Journal of Accounting and Economics, 3, 183-199. http://dx.doi.org/10.1016/0165-4101(81)90002-1

Defond, M. L. (1992). The association between change in client firm agency costs and auditor switching. Auditing: A Journal of Practice and Theory, 11, 16-31.

Deis, D. R., \& Giroux, G. A. (1992). Determinants of audit quality in the public sector. The Accounting Review, $67,462-479$.

Dye, R. A. (1993). Auditing standards, legal liability, and auditor wealth. Journal of Political Economy, 101, 887-914. http://dx.doi.org/10.1086/261908

Elder, R. J., Beasley, M. S., \& Arens, A. A. (2008). Auditing and assurance services: an integrated approach. New Jersey: Pearson Education.

Fasci, M. A., \& Valdez, J. (1998). A performance contrast of male- and female-owned small accounting practices. Journal of Small Business Management, 36, 1-7.

Feltham, G. A., Huges, J. S., \& Simunic, D. A. (1991). Empirical assessment of the impact of auditor quality on the valuation of new issues. Journal of Accounting and Economics, 14, 375-399. http://dx.doi.org/10.1016/0165-4101(91)90009-D

Francis, J. R. (1984). The effect of audit firm size on audit prices. Journal of Accounting and Economics, 6, 133-151. http://dx.doi.org/10.1016/0165-4101(84)90010-7

Francis, J. R., Maydew, E. L., \& Sparks, C. H. (1999). The role of big 6 auditors in the credible reporting of accruals. Auditing: A Journal of Practice and Theory, 18, 17-34. http://dx.doi.org/10.2308/aud.1999.18.2.17

Francis, J. R., \& Wilson, E. R. (1988). Auditor changes: A joint test of theory relating to agency costs and auditor differentiation. The Accounting Review, 63, 663-682.

FRC, Financial Reporting Council. (2006). Promoting audit quality. London: FRC Press Releases.

Gale, B. T., \& Swire, D. J. (1977). The limited information report: A strategic planning tool for business decision making when information is difficult to obtain. Massachusetts: Strategic Planning Institute.

Geletkanycz, M. A., \& Hambrick, D. C. (1997). The External ties of tp executives: implications for strategic choice and performance. Administrative Science Quarterly, 42, 654-681. http://dx.doi.org/10.2307/2393653

Ghosh, A., \& Lustgarten, S. (2006). Pricing of initial audit engagements by large and small audit firms. Contemporary Accounting Research, 23, 333-368. http://dx.doi.org/10.1506/927U-JGJY-35TA-7NT1

Ghosh, A., \& Moon, D. (2005). Auditor tenure and perceptions of audit quality. The Accounting Review, 80, 585-612. http://dx.doi.org/10.2308/accr.2005.80.2.585

Grotelueschen, A. D. (1990). The effectiveness of mandatory continuing education for licensed accountants in public practice in the state of New York. New York, NY: State Education Department.

Goldman, A., \& Barlev, B. (1974). The auditor-firm conflict of interests: Its implications for independence. The Accounting Review, 49, 707-718.

Gul, F. A. (1999). Audit prices, product differentiation and economic equilibrium. Auditing: A Journal of Practice and Theory, 18, 90-100. http://dx.doi.org/10.2308/aud.1999.18.1.90

Gyimah-Brempong, K. (1987). Economies of scale in municipal police department: The case of Florida. Review of Economics and Statistics, 69, 352-356. http://dx.doi.org/10.2307/1927244

Hall, W. K. (1980). Survival strategies in a hostile environment. Harvard Business Review, 58, 75-85.

Kiechel, W. (1981). Three (or four, or more) ways to win. Fortune, 104, 181-189.

Klein, B., \& Leffler, K. B. (1981). The role of market forces in assuring contractual performance. Journal of Political Economy, 89, 615-641. http://dx.doi.org/10.1086/260996

Krishnan, J., \& Schauer, P. C. (2000). The differentiation of quality among auditors: Evidence from the 
not-for-profit sector. Auditing: A Journal of Practice and Theory, 19, 9-25. http://dx.doi.org/10.2308/aud.2000.19.2.9

Lee, C. W., Liu, C. W., \& Wang, T. C. (1999). The 150-hour rule. Journal of Accounting and Economics, 27, 203-228. http://dx.doi.org/10.1016/S0165-4101(99)00010-5

Liu, C. (1997). Legal liability, human capital investment, and audit quality. Ph.D dissertation, University of National Taiwan University, Taiwan.

Meinhardt, J., Moraglio, J. F., \& Steinberg, H. I. (1987). Governmental audits: an action plan for excellence. Journal of Accountancy, 164, 86-91.

Milgrom, P., \& Roberts, J. (1990). The economics of modern manufacturing. American Economics Review, 80, 511-528.

Nichols, D. R., \& Price, K. H. (1976). The auditor-firm conflict: An analysis using concepts of exchange theory. The Accounting Review, 51, 335-346.

Niemi, L. (2004). Auditor size and audit pricing: evidence from small audit firms. European Accounting Review, 13, 541-560. http://dx.doi.org/10.1080/0963818042000237151

O'Keefe, T. B., \& Westort, P. J. (1992). Conformance to GAAS reporting standards in municipal audits and the economics of auditing: the effects of audit firm size, CPA examination performance, and competition. Research in Accounting Regulation, 6, 39-77.

Palmrose, Z. V. (1988). An analysis of auditor litigation and audit service quality. The Accounting Review, 63, $55-73$.

Pedhazur, E. J. (1982). Multiple regression in behavior research: Explanation and prediction. New York, NY: Rinehart and Winston.

Phillips, L. W., Chang, D. R., \& Buzzell, R. D. (1983). Product quality, cost position, and business performance: A test of some key hypothesis. Journal of Marketing, 47, 26-43. http://dx.doi.org/10.2307/1251491

Porter, M. E. (1980). Competitive strategy. New York, NY: The Free Press.

Rescho, J. A. (1987). Public accounting firm strategy and Innovativeness: A study of the adoption of product, technical, and administrative innovations using a strategic typology. Ph.D dissertation, University of Mississippi, Oxford, Mississippi, United States.

Reynolds, J. K., \& Francis, J. R. (2001). Does size matter? The influence of large clients on office-level auditor reporting decision. Journal of Accounting and Economics, 30, 375-400. http://dx.doi.org/10.1016/S0165-4101(01)00010-6

Schoeffler, S., Buzzell, R. D., \& Heany, D. F. (1974). Impact of strategic panning on profit performance. Harvard Business Review, 52, 137-145.

Shapiro, C. (1983). Premiums for high quality products as returns to reputations. Quarterly Journal of Economics, 98, 659-679. http://dx.doi.org/10.2307/1881782

Simunic, D. A., \& Stein, M. T. (1987). Product differentiation in auditing: Auditor choice in the market for unseasoned new issues. Vancouver: The Canadian Certified General Accountants' Research Foundation.

Taylor, M. H., \& Simon, D. T. (1999). Determinants of audit fees: the importance of litigation, disclosure, and regulatory burdens in audit engagements in 20 countries. International Journal of Accounting, 34, 375-388. http://dx.doi.org/10.1016/S0020-7063(99)00017-5

Teoh, S. H., \& Wong, T. J. (1993). Perceived auditor quality and the earnings response coefficient. The Accounting Review, 68, 346-366.

Venkataraman, R., Weber, J. P., \& Willenborg, M. (2008). Litigation risk, audit quality, and audit fees: Evidence from initial public offerings. The Accounting Review, 83, 1315-1345. http://dx.doi.org/10.2308/accr.2008.83.5.1315

Watkins, A. L., Hillison, W., \& Morecroft, S. E. (2004). Auditor quality: A synthesis of theory and empirical evidence. Journal of Accounting Literature, 23, 153-193.

Watts, R. L., \& Zimmerman, J. L. (1986). Positive accounting theory. New Jersey, Prentice Hall.

Wallace, W. A., \& Campbell, R. L. (1988). State boards of accountancy: Quality review and positive enforcement programs. Research in Accounting Regulation, 2, 123-154. 
Whittington, O. R., \& Pany, K. (2003). Principle of auditing and other assurance services. New York, NY: McGraw-Hill.

\section{Copyrights}

Copyright for this article is retained by the author(s), with first publication rights granted to the journal.

This is an open-access article distributed under the terms and conditions of the Creative Commons Attribution license (http://creativecommons.org/licenses/by/3.0/). 